\title{
Formation of Effective Mechanism for Financial Recovery of Agricultural Organization
}

\author{
Lavlinskaya A.L.* \\ Chair of Finance and Credit \\ Voronezh state agrarian university \\ Voronezh, Russia \\ Anna_Levonovna@mail.ru
}

Panina Ye.B.

Chair of Economical Analysis, Statistics and Applied Mathematics

Voronezh state agrarian university

Voronezh, Russia

yelena.panina2014@yandex.ru

\author{
Aleshchenko O.M. \\ Chair of Finance and Credit \\ Voronezh state agrarian university \\ Voronezh, Russia \\ Arapova1979@mail.ru \\ Kuznetsova I.V. \\ Chair of Accounting and Audit \\ Voronezh state agrarian university \\ Voronezh, Russia \\ Irina197906@mail.ru
}

\begin{abstract}
The article gives recommendations on the formation of an effective mechanism for financial recovery of agricultural organizations. It is proposed to interpret financial recovery as a system of goals, principles, financial methods and financial instruments for the development and implementation of a set of special management decisions aimed at preventing and overcoming crisis phenomena in order to achieve solvency and long-term financial stability of the organization. It is concluded that the legal and organizational forms of the organization's financial recovery depend on what causes the crisis, at what crisis stage the actions against it began. On this basis, a model has been developed for the relationship between types of crises, financial indicators, and the financial recovery mechanism, which helps to identify the degree of crisis and ensure the interference of strategic, tactical, and operational crisis management. The feasibility of using a matrix of financial equilibrium is substantiated. This matrix was designed to predict the "critical path" of the organization's development for the coming years, identify the acceptable limits of risk and the threshold of its potential for the purpose of forming a strategy for overcoming the crisis and developing an appropriate mechanism for financial recovery using the example of a specific agricultural organization. Strategically oriented scenarios of financial recovery and the mechanism for their application for agricultural organizations are proposed, taking into account the scale and depth of financial insolvency, the prospects and opportunities for an independent exit from the crisis, as well as target indicators for their implementation from the standpoint of satisfying the interests of the business owner and creditors. The application of the proposed mechanism by agricultural organizations will identify crisis phenomena at an early stage and promptly make managerial decisions for financial recovery. This will lead to strengthening financial stability, increasing the competitiveness of agricultural organizations, which, in turn, will ensure the stable functioning of the agricultural sector, food security of the state and will contribute to the development of the country's economy and GDP growth.
\end{abstract}

Keywords - financial recovery, crisis, agricultural organizations.

\section{INTRODUCTION}

Any socio-economic systems, including commercial organizations, are prone to crises. These crises are due to both the high speed and the negative nature of the transformation of external economic conditions, and internal reasons associated with the low level of production, marketing and supply organization, the use of outdated production technologies, violation of payment and settlement discipline and other factors.

Crisis affects all organizations at any stage of the life cycle. According to the Center for Macroeconomic Analysis and Short-Range Forecasting, in the first quarter of 2019, the agricultural sector of the Russian Federation showed a moderate increase in the number of bankruptcies: at the beginning of 2018 , about 36 legal entities on average went bankrupt a month in the industry, a year later their number was more than 50 [1]. And in modern conditions of 2020, organizations have to face a lot of difficulties, which may negatively affect their activities. In this regard, the formation of a mechanism for organizations to get out of a crisis and minimize its consequences is of particular relevance. Crisis management as a special area of knowledge is dedicated to this problem. A special role in the crisis management system is given to financial management and financial recovery of organizations. The importance of financial management in the face of the effects of crisis is due to the special role of finances in the organization's activities.

The concept of financial recovery is widely used in legal, financial and economic practice. The key regulatory acts reflecting the legal approach to financial recovery are the Federal Law "On Insolvency (Bankruptcy)" [2] and the Federal Law "On the Financial Recovery of Agricultural Commodity Producers" [3].

In the framework of the main legislative document governing insolvency issues, financial recovery is considered as one of the procedures applied to the debtor in order to 
restore their solvency and pay off debts in accordance with the established schedule. The main emphasis in the law is made mainly on the need to fulfill the obligations to creditors, and not on overcoming the crisis and restoring the financial balance of an insolvent enterprise. That is why financial recovery is considered as a passive pro-credit procedure, which has not found wide application in the practice of bankruptcies of Russian enterprises.

To remove one of the strategically important sectors of the domestic economy - the agrarian one - from the recession, the government developed the Federal Law "On the financial recovery of agricultural producers". In this document, the focus is primarily on the goal of financial recovery as improving the financial condition of agricultural producers. Debt restructuring is considered as the main tool to achieve the goal of the state policy of financial recovery of agricultural producers. The procedure and conditions for restructuring debts are determined depending on the group of financial stability of the debtor. The group the debtor belongs to is determined according to the methodology for calculating indicators of the financial condition of agricultural producers included in the recovery program.

Using this program, many agricultural producers were able to overcome the crisis and restore their solvency through deferral and installment payment of overdue debts to the budget, extra-budgetary funds, banks, suppliers and other creditors.

However, it is worth noting that the law does not contain a direct definition of financial recovery. Thus, despite the importance of this document, it focuses only on the use of one of the tools for financial recovery (debt restructuring) and contains neither other measures to bring agricultural producers out of the crisis nor preclusive measures to prevent it.

The development of agricultural economics is the subject of the work of many economists [4-7], the problems of financial recovery and bankruptcy of organizations were studied in the works by B. Iverson [8], T. Kliestik [9], K. Mitman [10], G. Pratt [11], S. G. Belyaev [12], A.Z. Bobyleva [13], E.P. Zharkovskaya [14], Z.A. Krush [15], O.P. Zaitseva [16], I.A. Blank [17], K.V. Baldin [18] and others.

At the same time, despite the experience gained in Russia in crisis management and a significant amount of scientific work devoted to this topic, the holistic mechanism of financial recovery has not yet become the subject of a special study, and its formation and development at agricultural organizations requires further development.

Currently, the economic literature does not fully develop the conceptual foundations for the formation of this mechanism, taking into account its relationship with the general management system at agricultural organizations. So far, agricultural economists have not studied the reliability of existing methods for assessing the financial situation and the degree of crisis in order to develop and improve the financial recovery mechanism. The signs of the crisis state of agricultural organizations, their early symptoms and causeeffect relationships are not structured.
Therefore, in practice, it turned out that the positive results of countering crisis and the danger of bankruptcy of agricultural organizations are the exception rather than the rule.

We believe that the financial recovery of the organization implies the creation of conditions for the stable maintenance of its financial equilibrium and financial stability in the long term. In our opinion, only the most efficient use of all the organization resources allows full realization of its potential and provision of necessary basis for its long-term financial viability.

In this regard, we propose to interpret financial recovery as a system of goals, principles, financial methods and financial instruments for the development and implementation of a set of special management decisions aimed at preventing and overcoming crisis phenomena in order to achieve solvency and long-term financial stability of the organization.

\section{MATERIALS AND METHODS}

As part of the diagnosis of the financial and economic situation, it is important to determine the causes of the crisis, to conduct a study of the degree of individual factors influence on the scale and form of the financial crisis in the context of individual parameters of the enterprise in the crisis area.

Feinschmidt E. [19] identifies three main groups of causes leading organizations to a crisis. The first group of reasons is related to dishonesty of the organization's leaders or its individual employees, who, abusing their official position, harm companies in various ways (transfer the organization's assets to their personal property, execute "orders" of competitors or individual suppliers, consumers or creditors of the company).

The second group of reasons is related to the wrong choice of the strategic vector of the organization's development. It is due to mistakes of management and top management, when they, having incorrectly assessed the organization's strategic financial position in the market, carry out ineffective investment projects that lead to loans, losses and insolvency of the organization.

The third group of reasons for the crisis of companies in a market economy is associated with an unfavorable general economic situation. During periods of general economical crisis, commercial organizations through no fault of their own fall into the conditions of a decrease in sales, violation of commercial agreements by buyers and suppliers, tightening of banks' credit policies, growth in tax burden, which ultimately leads to a drop in profits and a lack of cash, the appearance of past due obligations to the creditors. If this chain of default is not interrupted, the organization becomes insolvent and goes bankrupt.

A study of scientific publications $[13,15,20]$ made it possible to systematize and link together the type of the crisis, its signs and key financial indicators (Table 1). 
TABLE I. RELATIONSHIP OF THE TYPES OF CRISES IN THE ORGANIZATION, THEIR SIGNS, FINANCIAL INDICATORS AND THE MECHANISM OF FINANCIAL RECOVERY

\begin{tabular}{|l|l|l|l|l|}
\hline \multicolumn{1}{|c|}{$\begin{array}{c}\text { Type of } \\
\text { crisis }\end{array}$} & \multicolumn{1}{|c|}{ Key Signs of the Crisis } & \multicolumn{1}{|c|}{ Financial indicators of the crisis } & $\begin{array}{l}\text { Financial recovery } \\
\text { mechanism }\end{array}$ & \multicolumn{1}{|c|}{ Financial recovery tools } \\
\hline $\begin{array}{l}\text { Crisis of } \\
\text { strategy }\end{array}$ & $\begin{array}{l}\text { the growth rate of financial and } \\
\text { economic indicators lags } \\
\text { significantly behind the dynamics } \\
\text { of macroeconomic indicators of the } \\
\text { national economy (or the rate of } \\
\text { decline of indicators is above the } \\
\text { decrease in macroeconomic } \\
\text { indicators of the economy) }\end{array}$ & $\begin{array}{l}\text { the increase of weighted average cost of } \\
\text { capital (WACC), reduction in economic } \\
\text { value added (EVA), market value added } \\
\text { (MVA), cash value added (CVA); } \\
\text { internal growth rate (g) is below the } \\
\text { sustainable growth rate (SGR); failure to } \\
\text { comply with the golden economic rule }\end{array}$ & strategic mechanism & resource efficiency growth \\
investment resources
\end{tabular}

The most destructive for the organization is the crisis of strategy. It is a reflection of the inefficiency of the organization's functioning strategy chosen by managers. The sources of the strategic crisis are incorrect managerial decisions in the core business, customer selection, determination of key success factors. It is very difficult to identify the presence of such crisis in the early stages of the organization's functioning.

If it is possible to identify a crisis of the strategy in the early stages, then to eliminate it, a strategic mechanism for financial recovery should be developed.

At the initial stage, it is aimed to preserve the business value from destruction, and then to ensure balanced growth of the business, accompanied by an increase in its fundamental value. The instrument of the strategic mechanism is, first of all, the development of an effective investment strategy aimed at making investments not only in maintaining the functioning of the business, but also in its development.

The lack of proper attention to the problems of maintaining and growth of business value leads to the next type of crisis, structural. The structural crisis is manifested in a sales decrease, overstocking of the organization in connection with an incorrectly formed marketing policy. The consequence of this crisis is a low level of business profitability, which does not provide self-financing, and in the long run the selfsufficiency of the organization. The cause of the structural crisis is an ineffective development strategy of the organization (including financial strategy). Therefore on this stage, the tools of the strategic and tactical mechanisms should be used for its financial recovery. The goal of the tactical management is to maintain financial equilibrium, which should be considered as a necessary condition for avoiding insolvency and bankruptcy. To achieve this goal, it is necessary to revise the policy of formation and distribution of profits, the policy of managing capital and working capital.
If the structural crisis was not identified in time and (or) measures to neutralize it did not bring the desired effect, then a profitability crisis arises. In this case, the organization ceases to be profitable and goes into the unprofitable zone.

Thus, we can note the relationship and a certain subordination of the crisis types considered. The exception is the liquidity crisis. This type of crisis is not always the result of a structural or a profitability crisis. It can arise both in parallel with any type of crisis, or independently. This is due to the special nature of the liquidity crisis, which occurs because of the imbalance of payment and settlement transactions, leading to inconsistencies in the inflow and outflow of funds in time and in amounts. As a result, payment and settlement discipline is violated, overdue debts appear, contractors are forced to impose penalties to the organization.

If at this stage the organization is profitable, the level of profitability complies with the planned parameters, then it is possible get out of this crisis by using the operational mechanism of financial recovery. This mechanism is aimed primarily at adjusting the credit policy, the policy of managing current assets and liabilities, operational planning and regulation of cash flows, the use of instruments for equalizing and balancing cash flows [21].

However, the emergence of a liquidity crisis may have deeper roots. In this case, the application of the operational mechanism of financial recovery is required, and in some cases (if the cause of the liquidity crisis is the crisis of the strategy) strategic mechanism is also needed.

The consideration of the features of the formation of the financial recovery mechanism of an agricultural organization using the example of Agrofirm Kalitva LLC, Rossoshansky district, Voronezh region, allowed the following conclusions: 
- The structure of property and the structure of capital are irrational;

- The balance structure is irrational (the balance is illiquid);

- The loss making in production and commercial activities, as well as the inefficient use of assets, contributes to a further decrease in its financial stability and financial well-being and, in the long run, may cause its financial insolvency;

- In the near future, the organization has a real threat of losing solvency;

- The type of financial stability is crisis;

- The estimation of the bankruptcy probability (using models: liquidation value, five-factor model of E. Altman, Tuffler's Z-index) showed a high degree of bankruptcy probability;

- The integral assessment of financial condition showed the stage of financial instability close to the border of apparent bankruptcy;

- Based on the revealed relationship between the type of crisis, its signs and indicators, we determined that Agrofirm Kalitva LLC is in a structural crisis that has affected all the dominant areas of business: production, supply, marketing, personnel and finance. This situation is threatening legal and economic viability. To get out of it, it is advisable to use strategic, tactic and operational mechanisms for the financial recovery.

\section{RESULTS AND DISCUSSIONS}

To formulate a strategy for overcoming the crisis and develop an appropriate mechanism for financial recovery, it is recommended to use a matrix of financial equilibrium (a matrix of financial strategies). The matrix helps to predict the "critical path" of an organization for the coming years, outline acceptable limits of risk and identify the threshold of its capabilities.

Based on the accepted values of the indicators of the economic activity result (EAR) and the financial activity result (FAR), the position of Agrofirm Kalitva LLC was determined and a project of movement was developed according to the matrix of financial strategies (Fig. 1).

\begin{tabular}{|c|c|c|c|}
\hline & FAR $<0$ & FAR $\approx 0$ & FAR $>0$ \\
\hline 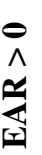 & 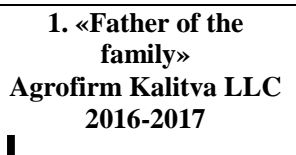 & 4. «Rentier» & $\begin{array}{l}\text { 6. «Maternal } \\
\text { society» }\end{array}$ \\
\hline 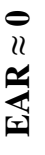 & $\begin{array}{l}\text { 7. «Episodic deficit» } \\
\text { PROJECT }\end{array}$ & $\begin{array}{l}\text { 2. «Sustainable } \\
\text { equilibrium» } \\
\text { PROJECT }\end{array}$ & 5. «Attack» \\
\hline 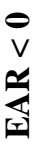 & 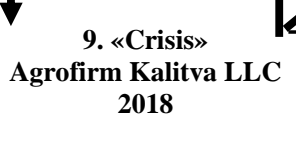 & 8. «Dilemma» & $\begin{array}{l}\text { 3. «Unstable } \\
\text { equilibrium» }\end{array}$ \\
\hline
\end{tabular}

Fig. 1. The position of Agrofirma Kalitva LLC on the matrix of financial strategies by Franchon and Romane and the project of its future movement

The calculations indicate a significant deterioration in the position of the organization and its movement from the zone of creation of liquid assets (square 1 "Father of the family") to the zone of deficit of liquid assets (square 9 "Crisis").

Given the insolvency factors of Agrofirm Kalitva LLC, the type of crisis, its depth and the extent of penetration, four strategic scenarios for the financial recovery of the organization have been developed (Table 2).

TABLE II. STRATEGIC SCENARIOS FOR FINANCIAL RECOVERY OF AGROFIRM KALITVA LLC

\begin{tabular}{|c|c|c|c|c|}
\hline \multirow{2}{*}{ Strategy aspects } & \multicolumn{4}{|c|}{ Financial recovery scenarios } \\
\hline & Target & Investment & Radical & Inertial \\
\hline Strategy content & Mobilization of internal reserves & $\begin{array}{l}\text { Involving a strategic } \\
\text { investor }\end{array}$ & Reorganization of a legal entity & $\begin{array}{l}\text { Bankruptcy procedures } \\
\text { introduction }\end{array}$ \\
\hline Target & $\begin{array}{l}\text { Bankruptcy prevention. Financial } \\
\text { equilibrium procuring. }\end{array}$ & $\begin{array}{l}\text { Saving the enterprise as a } \\
\text { holistic business. Way } \\
\text { out of the crisis. } \\
\text { Achieving high growth } \\
\text { rate. }\end{array}$ & $\begin{array}{l}\text { Conclusion of a profitable transaction } \\
\text { on the reorganization of a legal entity } \\
\text { (by merging, joining, splitting, } \\
\text { transforming an organization into an } \\
\text { open joint-stock company for the } \\
\text { purpose of partially selling assets). }\end{array}$ & $\begin{array}{l}\text { Repayment of obligations } \\
\text { to creditors. }\end{array}$ \\
\hline Target indicators & $\begin{array}{l}\text { Breakeven, self-sufficiency, } \\
\text { solvency. }\end{array}$ & $\begin{array}{l}\text { Self-financing. Achieving } \\
\text { high growth rate. }\end{array}$ & $\begin{array}{l}\text { Justification of the high cost of the } \\
\text { business and its perspective potential. }\end{array}$ & $\begin{array}{l}\text { Repayment of obligations } \\
\text { to creditors. }\end{array}$ \\
\hline Subjects & Special team or crisis team. & Special team. & Special bipartite team. & External manager. \\
\hline $\begin{array}{l}\text { The nature of the } \\
\text { activities used }\end{array}$ & Offensive. Protective. & Offensive. & Offensive. Protective. & Protective. \\
\hline Basic tools & $\begin{array}{l}\text { Participation in the state program } \\
\text { for the financial rehabilitation of } \\
\text { agricultural organizations. Tax and } \\
\text { budget credit. Optimization of } \\
\text { business processes. Reducing } \\
\text { running costs. Debt recovery. } \\
\text { Daily monitoring of the financial } \\
\text { and economic situation. }\end{array}$ & $\begin{array}{l}\text { Implementation of } \\
\text { investment projects. }\end{array}$ & $\begin{array}{l}\text { Estimation of liquidation value. } \\
\text { Valuation of the economic potential of } \\
\text { a business. Calculation of economic } \\
\text { value and FCF. }\end{array}$ & $\begin{array}{l}\text { Implementation of } \\
\text { measures within the } \\
\text { framework of bankruptcy } \\
\text { procedures in accordance } \\
\text { with effectual legal } \\
\text { system. }\end{array}$ \\
\hline
\end{tabular}


The targeted strategy for financial recovery of Agrofirm Kalitva LLC is aimed at restoring solvency and normalizing the liquidity of the organization with internal forces as soon as possible. In other words, it is necessary to identify key measures aimed at increasing revenue, reducing costs and mobilizing cash resources for urgent repayment of current obligations.

In order to pay off monetary obligations and obligatory payments, to restore the solvency of the organization on the basis of attracting budgetary and extra-budgetary funds, it is advisable to use a set of financial instruments that allow the organization to activate internal reserves.

As a mechanism for attracting budget funds, it is recommended to use such financial instruments as tax and budget loans, joining the financial recovery program in accordance with the Federal Law "On the financial recovery of agricultural producers".

The mechanism of the financial recovery program in accordance with federal law provides for state preferences: "freezing" of debts on administrative penalties, fines and penalties, budget loans and borrowings, taxes. Installments payable is proposed up to five years. These measures will allow the organization to reduce debt tensions, reduce monthly expenses and reach breakeven.

As a mechanism for attracting extrabudgetary funds, it is offered to use such financial instruments as assignment of claims as debt repayment, factoring, leasing, suppliers' loans and prepayments of buyers, sale of nonfunctioning assets through open or closed bidding and a bonded loan. These financial instruments are aimed at reducing accounts receivable, saving money and increasing the organization's cash revenue.

To implement the target scenario of financial recovery, a special team or crisis team is needed, which is a composition of managers and specialists united by a common goal and interests related to financial recovery and the development of the organization, who is professionally trained and able to achieve this goal.

The main function of such specialists who regularly participate in the financial recovery of troubled companies is the use of proven methods adapted to the conditions of a particular organization to increase the efficiency of overcoming the crisis. In addition to the healing function, the involvement of crisis management specialists performs a signaling function. The authoritative opinion of these specialists on the condition of a financially unstable company and their personal experience will be a positive signal for creditors. It is important that the specialists included in the crisis team have a good reputation and cherish it, otherwise their conclusion about the state of the business will not cause creditors due trust.

Since the key "sore point" of Agrofirm Kalitva LLC is the loss-making of industrial and commercial activities, we consider it advisable to find opportunities to improve the production efficiency of the main types of products for the future. To justify this, we carried out predictive calculations using the operational analysis method. The calculations showed that implementing measures to optimize the cost structure of production and sales, as well as adjusting the pricing policy Agrofirma Kalitva LLC has real opportunities to increase the profitability of production and commercial activities.

If the enterprise does not succeed in overcoming the crisis on its own, then it is necessary to move on to an investment strategy.

It implies the search of an external investor ready to take on debt repayment for a financially unstable, but promising company. If successful, the transaction between the owner and the external investor allows lenders to fully receive the payments, the owner to maintain his reputation and avoid bankruptcy of the company, and the external investor to benefit from the acquired business.

In the absence of a strategic investor and the impossibility of overcoming the crisis on their own, a radical strategy aimed at reorganizing or selling the organization should be used.

In situations where the company is insolvent, the asymmetry of information between the owner and companies involving the merger or acquisition of an unstable organization leads to the need to determine the future economic potential of the company and its residual value. The owner is interested in preventing bankruptcy at all costs, and it is beneficial for him to conduct a restructuring transaction. The purpose of this scenario for the organization is, regardless of the true prospects of the organization, to try to convince partners that it will bring high income in the future.

The most undesirable scenario is the implementation of an inertial strategy involving the introduction of judicial procedures with the help of an arbitration manager. His powers include measures to restore the solvency of the debtor organization and the further implementation of its activities. External management ends either with the termination of the insolvency (bankruptcy) proceedings of the debtor organization, if the goal of the external management is successfully achieved, or by the decision to declare the debtor insolvent (bankrupt) and to commence bankruptcy proceedings

When implementing this strategy, creditors and the owner are determined to liquidate the organization, which consists in the dissolution of the problem company and the sale of its assets at auction.

In each case, the choice between the considered scenarios of financial recovery should be made individually, taking into account industry conditions, company prospects, liquidity of assets, costs of a particular procedure and other factors.

The main criterion that determines the logic of owners, investors and creditors' behavior in a crisis is the degree of reliability of information about the prospects and internal potential of the organization.

\section{CONCLUSION}

To sum up, organizations are subject to all sorts of crises. The legal and organizational forms of financial recovery of the 
organization depend on what causes the crisis, at what stage of the crisis the struggle began. In general, to improve the effectiveness of management decisions in the field of financial recovery, it is advisable to use a combination of various tools.

We emphasize that the sooner crisis phenomena are detected, the faster correct management decisions are made, the less negative consequences the crisis will bring, the more effective and painless will be the measures to neutralize it.

The formation of an effective mechanism for financial recovery of agricultural organizations will ensure the strengthening of their financial stability, competitiveness and technological modernization of agriculture, the stable functioning of the agricultural sector, food security of the state and will contribute to the development of the country's economy and GDP growth.

\section{References}

[1] Bankruptcies of legal entities in Russia: main trends. Center for Macroeconomic Analysis and Short-Range Forecasting. Retrieved from: http://www.forecast.ru/default.aspx

[2] On the insolvency (bankruptcy) of enterprises: Federal Law of 11.26.2002, no. 127-FZ. Retrieved from: https://base.garant.ru/185181/

[3] On the financial recovery of agricultural producers: Federal Law of 09.07.2002, no. 83-FZ. Retrieved from: https://base.garant.ru/12127364/

[4] S.A. Gorlanov, Z.P. Medelyaeva, V.B. Malitskaya, M.B. Chirkova, E.I. Kostyukova, "Content analysis the term "effectiveness" and the concepts of its quantitative characteristics", Indo Amer. J. of Pharmac. Sci., vol. 6, no. 3, pp. 5293-5298, 2019.

[5] A.V. Agibalov, Y.V. Tkacheva, L.A. Zaporozhtseva, "Improvement of the financial management strategy for agricultural enterprises", J. of Econ. and Manag. Perspect., vol. 11, no. 3, pp. 1686-1696, 2018.

[6] A. Agibalov, L. Zaporozhtseva, V. Malitskaya, M. Chirkova, N.Gorlova, "Model Development to Ensuring the Enterprise Financial Security",
Int. J. of Recent Technol. and Engineer. (IJRTE), vol. 8, iss. 4, pp. 12196-12199, November 2019.

[7] L. Zaporozhtseva, V. Malitskaya, M. Chirkova, Yu. Tkacheva, I. Kuznetsova, "Financial mechanism for commercial development organizations: vector approach", Int. Transact. J. of Engineer., Manag., \& Appl. Sci. \& Technolog., vol. 11, no. 7, paper ID:11A07B.

[8] B. Iverson, "Get in line: Chapter 11 restructuring in crowded bankruptcy courts”, Manag. Sci., vol. 64.11, pp. 5370-5394, 2018.

[9] T. Kliestik et al., "Bankruptcy prevention: new effort to reflect on legal and social changes", Sci. and Engineer. Ethics, vol. 24.2, pp. 791-803, 2018.

[10] K. Mitman, "Macroeconomic effects of bankruptcy and foreclosure policies", Amer. Econ. Rev., vol. 106.8, pp. 2219-55, 2016.

[11] G. Pratt, D. Graves, Michelle Arnopol Cecil, "Harmonizing Conversion and the Means Test in Bankruptcy", Bus. Entrepreneurship \& Tax L. Rev., vol. 3, p. 36, 2019).

[12] S.G. Belyaev, V.I. Koshkina, Theory and practice of crisis management. Moscow, 2010, 325 p.

[13] A.Z. Bobyleva, Financial recovery of the company. Theory and Practice. Moscow, 2004, $256 \mathrm{p}$.

[14] E.P. Zharkovskaya, B.E. Brodsky, Crisis Management. Moscow, 2011, $467 \mathrm{p}$.

[15] Z.A. Krush, L.V. Lushchikova, Anti-crisis financial management of commercial organizations. Voronezh, 2001, $316 \mathrm{p}$.

[16] O.P. Zaitseva, "Formation of analytical tools for financial recovery of an organization", Econ. anal., vol. 1, no. 62, pp. 70-75, 2007.

[17] I.A. Blank, Anti-crisis financial management of an enterprise. Moscow: Nika-Center, Elga, 2006, 672 p.

[18] K.V. Baldin, Anti-crisis Management. 2007, 316 p.

[19] E.A. Fainshmidt, "Foreign methods of financial recovery of enterprises", Property relations in the Russ. Fed., vol. 11, no. 38, pp. 59-76, 2004.

[20] M.I. Gizatulin, Methods of financial recovery of enterprises (Cand. Dissertation thesis). Moscow, 2003, 20 p.

[21] A.L. Lavlinskaya, "Strategy of current assets management as the basis for the successful development of agricultural enterprises", Econ. of agricult. and processing enterprises, no. 2, pp. 42-46, 2017. 